\title{
PELAKSANAAN LAYANAN BIMBINGAN KELOMPOK UNTUK MENINGKATKAN DISIPLIN BELAJAR PESERTA DIDIK
}

\section{Implementation Of Group Guiding Services To Improve Discipline Learning Students}

\author{
'Anita, ${ }^{2}$ M. Fatchurahman \\ IUniversitas Muhammadiyah Palangkaraya, Jekan Raya, Palangka Raya, Kalimantan Tengah, Indonesia \\ 2 Universitas Muhammadiyah Palangkaraya, Jekan Raya, Palangka Raya, Kalimantan Tengah, Indonesia
}

\section{ARTIKEL INFO}

\section{Diterima}

Juni 2018

Dipublikasi

Agustus 2018

*E-mail:

Mfatchurahman@gmail.com

\begin{abstract}
Tujuan penelitian ini untuk meningkatkan disiplin belajar peserta didik di di MTs Miftahul Jannah Palangka Raya dengan menggunakan layanan bimbingan kelompok. Populasi dalam penelitian ini berjumlah 32 orang peserta didik. Jumlah sampel penelitian terdiri dari 8 orang peserta didik. Pengambilan sampel ditentukan dengan teknik Random Sampling. Teknik pengumpulan data menggunakan observasi, wawancara, dan skala disiplin belajar. Metode yang digunakan adalah preeksperimen, teknik pengumpulan data menggunakan rumus Paired-Sample T Test atau lebih dikenal dengan Pre-Post Design adalah analisis dengan melibatkan dua pengukuran pada subjek yang sama terhadap suatu pengaruh atau perlakuan tertentu. Hasil penelitian menunjukan bahwa: berdasarkan analisis dengan PairedSample T Test, menunjukkan bahwa disiplin belajar peserta didik mengalami peningkatan rata-rata awal 130,13 menjadi 234,13. Artinya "Layanan Bimbingan Kelompok Dapat Meningkatkan Disiplin Belajar Peserta Didik di MTs Miftahul Jannah Palangka Raya Tahun Ajaran 2016/2017”. Hasil analisis menunjukan bahwa kedelapan peserta didik pada subjek penelitian mengalami peningkatan disiplin belajar sesudah dilakukan intervensi.
\end{abstract}

ABSTRAK

Kata kunci: disiplin belajar, layanan bimbingan kelompok

\section{ABSTRACT}

The purpose of this study was to improve students' learning discipline at MTs Miftahul Jannah Palangka Raya by using group guidance services. The population in this study amounted to 32 students. The number of research samples consisted of 8 students. Sampling is determined by Random Sampling technique. Data collection techniques use observation, interviews, and the scale of learning discipline. The method used is preexperiment, the technique of collecting data using the Paired-Sample T Test formula or better known as Pre-Post Design is an analysis involving two measurements on the same subject against a particular influence or treatment. The results of the study show that: based on analysis with Paired-Sample T Test, it shows that students' learning discipline has an initial average increase of 130.13 to 234.13. This means "Group Guidance Services Can Improve Learning Discipline of Students at MTs Miftahul Jannah Palangka Raya 2016/2017 Academic Year". The results of the analysis show that the eight students in the research subject experienced an increase in learning discipline after intervention.

Keywords: learning discipline, group guidance services 
Jurnal Bimbingan dan Konseling

\section{PENDAHULUAN}

Peserta didik mampu mengembangkan potensi diri untuk mencapai tugas-tugas perkembangannya menyangkut aspek emosi dan moral yang ada di dalam diri peserta didik tersebut, selain itu peserta didik dipandang sebagai seorang individu yang sedang berkembang ke arah kematangan untuk mencapai kematangan tersebut peserta didik memerlukan bimbingan, karena peserta didik masih belum memiliki pengalaman dan wawasan tentang dirinya dan juga lingkungannya.

Menurut Yusuf (2012: 23) "peserta didik masa usia sekolah menengah berada pada usia 12 sampai dengan 18 tahun". Schneiders (dalam kemendikbud 2014: 20) menjelaskan karakteristik penyesuaian sosial remaja di lingkungan Sekolah: (a) bersikap respek dan mau menerima peraturan sekolah; (b) berpartisipasi aktif dalam kegiatan sekolah; (c) menjalin persahabatan dengan temanteman di sekolah; (d) bersikap hormat dan patuh terhadap guru dan semua personil sekolah: (e) membantu sekolah dalam merealisasikan tujuan-tujuannya.

Penyesuaian sosial remaja di sekolah terkait dengan pengendalian emosional secara seimbang sangat menentukan keberhasilan dalam perkembangan sosial remaja. Sikap saling pengertian dan kemampuan memahami orang lain merupakan modal utama dalam kehidupan dan dalam hal ini akan dengan mudah dicapai oleh remaja yang berkemampuan intelektual tinggi. Perkembangan emosional pada remaja akan berjalan dengan perkembangan moral. hal ini mendorong orang tua atau guru untuk berupaya mengajarkan moral pada anak. Moral yang baik melalui pemberian contoh atau teladan yang baik.

Peserta didik yang belum mencapai perkembagan moral secara optimal akan memunculkan perilaku negatif di sekolah. salah satu perilaku negatif peserta didik di sekolah adalah pelanggaran ketentuan sekolah. peserta didik yang acuh terhadap ketentuan sekolah adalah peserta didik yang cenderung kurang disiplin.

Menurut Rasdiyanah (2014:28) "disiplin yaitu kepatuhan untuk menghormati dan melaksanakan suatu sistem yang mengharuskan orang untuk tunduk pada keputusan, perintah atau peraturan yang berlaku. Peserta didik yang tidak disiplin memiliki dampak negatif. Menurut Syamsudin (2013: 02) Perilaku yang cenderung membuat siswa menjadi tidak lebih tertib dan teratur dalam menjalankan kehidupannya, serta peserta didik juga tidak dapat mengerti bahwa kedisiplinan itu amat sangat penting bagi masa depannya kelak, karena tidak dapat membangun kepribadian diri yang kokoh dan bisa diharapkan berguna bagi semua pihak.

Fenomena disiplin peserta didik yang sering terjadi disekolah misalnya tidak memperhatikan ketika guru menjelaskan pelajaranribut pada saat belajar, keluar masuk kelas pada saat jam pelajaran berlangsung, berjalan-jalan di kelas untuk meminjam alat tulis, ketinggalan buku pelajaran dan lupa membawa Pekerjaan Rumah (PR).

Menurut Slameto (2010: 2) "Belajar ialah suatu proses yang dilakukan seseorang untuk memperoleh suatu perubahan tingkah laku yang baru secara keseluruhan, sebagai hasil pengalamannya sendiri dalam interaksi dengan lingkungannya".

Disiplin belajar adalah suatu sikap, tingkah laku dan perbuatan siswa untuk melakukan aktivitas belajar yang sesuai dengan keputusan-keputusan, peraturan-peraturan dan norma-norma yang telah ditetapkan bersama, baik persetujuan tertulis maupun tidak tertulis antara siswa dengan guru di sekolah maupun dengan orang tua di rumah.

Fungsi disiplin Menurut Tulus Tu'u (2004: 38) antara lain: a) menata kehidupan bersama, fungsi displin adalah mengatur tata kehidupan manusia, dalam kelompok tertentu 
Jurnal Bimbingan dan Konseling

atau di masyarakat. Dengan begitu, hubungan antara individu satu dengan yang lain menjadi baik dan lancar; b) membangun kepribadian, lingkungan yang berdisiplin baik, berpengaruh terhadap kepribadian seseorang. Apabila seorang siswa yang sedang tumbuh kepribadianya, tentu lingkungan sekolah yang tertib, teratur, tenang, tentram, sangat berperan dalam membangun kepribadian yang baik; c) melatih kepribadian, sikap,perilaku dan pola kehidupan yang baik dan disiplin tidak terbentuk serta-merta dalam waktu singkat;

Jenis perilaku disiplin menurut Lembaga Ketahanan Nasional (2009: 14) adalah sebagai berikut:

I. Takwa kepada Tuhan YME;

2. Kepatuhan dinamis artinya bukan kepatuhan yang mati dalam mewajibkan seseorang untuk patuh;

3. Kesadaran artinya adanya kepatuhan yang sudah menyatu dengan hati dan perbuatan;

4. Rasional artinya kepatuhan melalui proses berpikir;

5. Sikap mental yang menyatu dalam diri, artinya kepatuhan yang sudah dijabarkan dalam setiap perilaku dan perbuatan, baik sebagai pribadi maupun sebagai warga yang bertanggung jawab terhadap bangsa dan Negara;

6. Keteladanan artinya setiap orang harus dapat menjadi teladan atau contoh yang baik bagi orang lain;

7. Keberanian dan kejujuran artinya sikap yang tidak mendua, yaitu sikap tegas dan lugas dalam menerapkan aturan atau sanksi.

Berdasarkan hasil Daftar Cek Masalah (DCM) dan observasi yang dilakukan peneliti pada tanggal 10 Januari 2016 di MTs Miftahul Jannah Palangka Raya., terdapat beberapa peserta didik yang terlambat datang kesekolah, terdapat peserta didik yang berpakaian kurang rapi, tidak memperhatikan saat guru menjelaskan materi pelajaran, dan peserta didik tidak menggunakan atribut lengkap saat upacara bendera, peserta didik tidak menolong teman yang memerlukan penjelasan materi yang belum dipahami.

Menurut Prijodarminto (2009: 23-24) ada tiga aspek disiplinsebagai berikut:

I. Sikap mental (mental attitude) yang merupakan sikap taat dan tertib sebagai hasil atau pengembangan dan latihan pengendalian pikiran dan pengendalian watak.

2. Pemahaman yang baik mengenai sistem atau perilaku, norma, kriteria, dan standar yang sedemikian rupa sehingga pemahaman tersebut memberikan pengertian yang mendalam atau kesadaran, bahwa ketaatan akan norma, aturan, kriteria dan standar tadi merupakan syarat mutlak untuk mencapai keberhasilan.

3. Sikap kelakuan secara wajar menunjukkan kesungguhan hati, untuk mentaati segala hal secara cermat dan tertib. Disiplin itu lahir, tumbuh dan berkembang dari sikap seseorang pada system nilai budaya yang telah ada didalam masyarakat, ada unsur yang membentuk disiplin yaitu sikap yang telah ada pada diri manusia dan sistem nilai budaya yang ada didalam masyarakat.

Menurut Bekti Ari (Kusumawati, 2012: I0-II) beberapa unsur yang terkandung dalam disiplin adalah sebagai berikut:

I) Taat

Taat artinya selalu patuh pada peraturan yang berlaku. Ketaatan di dalam disiplin belajar diperlukan supaya setiap waktu yang ada hanya untuk belajar dengan diimbangi dengan kegiatan lain.

2) Tetib

Tertib berarti mengerjakan kegiatan dengan kesadaran secara sistematis 
(terarah) yaitu di dalam kegiatan belajar sebaiknya siswa menentukan arah tujuan dari belajarnya sehingga dengan begitu akantercapai hasil yang efektif dan efisien

3) Tanggung jawab

Tanggung jawab adalah kegiatan yang dikerjakan dengan penuh rasa memiliki dan rasa menjaga agar setiap kegiatan yang dikerjakan betul-betul dapat dipercaya kebenarannya.Pada saat belajar diperlukan adanya rasa tanggung jawab dari dalam diri siswa supaya pada saat belajar menumbuhkan rasa meliki kewajiban untuk belajar sehingga akan membuat siswa lebih fokus pada pelajaran bukan hal lain.

Tu'u (2009: 48-50) menyebutkan bahwa,ada beberapa faktor disiplin, yaitu sebagai berikut:

I. Kesadaran diri sebagai pemahaman diri bahwa disiplin dianggap penting bagi kebaikan dan keberhasilan dirinya, selain itu kesadaran diri menjadi motif kuat terwujudnya disiplin.

2. Pengikutan dan ketaatan sebagai langkah penerapan dan praktik atas peraturan-peraturan yang mengatur perilaku individunya.

3. Alat pendidikan untuk mempengaruhi, mengubah, membina dan membentuk perilaku yang sesuai dengan nilai-nilai yang ditentukan atau diajarkan.

4. Hukuman sebagai upaya menyadarkan, mengoreksi dan meluruskan yang salah sehingga orang kembali pada perilaku yang sesuai dengan harapan.

Berdasarkan hasil wawancara dengan guru BK terkait dengan perilaku kurang disiplin belajar peserta didik, seperti peserta didik yang sering terlambat datang kesekolah, tidak menggunakan seragam lengkap saat upacara, terdapat peserta didik yang tidak mengerjakan dan mengumpulkan tugas yang diberikan oleh guru. Pihak sekolah dan guru
BK telah memberikan nasehat dan teguran, bahkan memberi sangsi terhadap peserta didik yang melanggar disiplin. Namun, guru BK belum melaksanakan layanan bimbingan kelompok kepada peserta didik agar dapat mentaati disiplin belajar di sekolah. Oleh sebab itu peneliti perlu melaksanakan layanan berupa bimbingan kelompok dalam meningkatkan disiplin belajar peserta didik di MTs Miftahul Jannah Palangka Raya.

Wibowo (2004: 17) menyatakan bahwa: Bimbingan kelompok adalah suatu kegiatan kelompok dimana pimpinan kelompok menyediakan informasi-informasi dan mengarahkan diskusi agar anggota kelompok menjadi lebih sosial atau untuk membantu anggota-anggota kelompok untuk mencapai tujuan-tujuan bersama

Menurut Wibowo, (2014: 17) Tujuan bimbingan kelompok yaitu: untuk memberi informasi dan data untuk mempermudah pembuatan keputusan dan tingkah laku. Gazda menyatakan bahwa bimbingan kelompok diorganisasikan untuk mencegah perkembangan masalah, yang isi utamanya meliputi informasi pendidikan, pekerjaan, pribadi, dan masalah sosial yang tidak disajikan dalam pelajaran.

Menurut Prayitno (2009: 40) ada empat tahap kegiatan yang perlu dilalui dalam pelaksanaan bimbingan kelompok, yaitu tahap pembentukan, peralihan, kegiatan, pengakhiran atau penutup.

\section{METODOLOGI PENELITIAN}

Metode penelitian yang digunakan dalam penelitian ini adalah metode eksperimen. Eksperimen menurut Arikunto (2013:3) adalah suatu cara untuk mencari sebab akibat (hubungan kausal) antara dua faktor yang segaja ditimbulkan oleh peneliti dengan mengurangi atau menyisihkan faktor-faktor lain yang bisa mengganggu. Jenis metode eksperimen dalam penelitian ini adalah pre-eksperimental design dengan menggunakan one group pre-test dan post-testdesign. Penelitian 
Jurnal Bimbingan dan Konseling

yang dilaksanakan pada satu kelompok saja tanpa kelompok pembanding.

Dalam penelitian ini observasi dilakukan sebanyak dua kali yaitu sebelum eksperimen dan sesudah eksperimen. Observasi sebelum dilakukan eksperimen (OI) disebut pre-test dan observasi sesudah eksperimen (O2) disebut post-test. Arikunto (2013:85) pertama dilakukan pengukuran (pre-test) terhadap peserta didik kemudian diberi perlakuan (treatment) bimbingan kelompok singkat berfokus solusi, (post-test) untuk melihat ada tidaknya pengaruh bimbingan kelompok yang diterapkan dalam upaya meningkatkan disiplin belajar. Pola dapat digambarkan sebagai berikut:

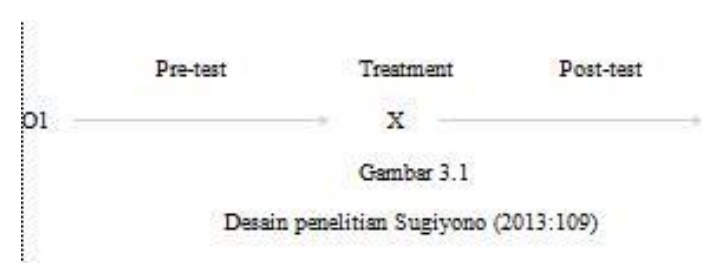

Populasi dalam penelitian ini adalah peserta didik Kelas VIII MTs Miftahul Jannah Palangka Raya. Menurut S. Margono( 2009:II8 ) "Populasi adalah seluruh data yang menjadi perhatian kita dalam suatu ruang lingkup dan waktu yang kita tentukan”. Sampel dalam penelitian ini berjumlah 8 orang.

Analisis yang digunakan dalam penelitian ini adalah analisis data Kuantitatif dengan teknik Paired-Sample T Test, Paired-Sample T Test atau lebih dikenal dengan Pre-post Design adalah analisis dengan melibatkan dua pengukuran pada subjek yang sama terhadap suatu pengaruh atau perlakuan tertentu. Pengukuran pertama dilakukan sebelum diberi perlakuan tertentu dan pengukuran kedua dilakukan sesudahnya. Dasar pemikirannya sederhana, yaitu bahwa apabila suatu perlakuan tidak memberi pengaruh maka perbedaan rataratanya nol (Trihendardi, 20I2:129).

\section{HASIL DAN PEMBAHASAN}

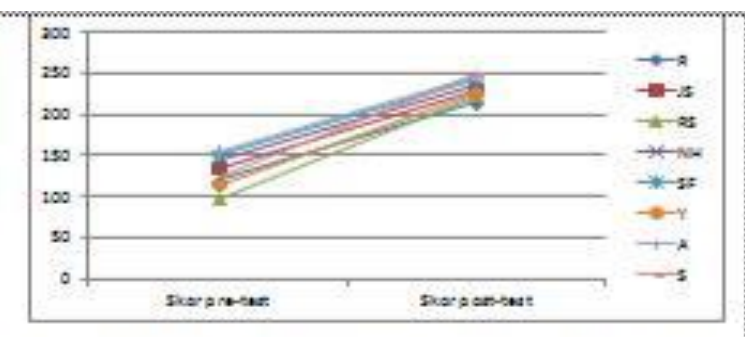

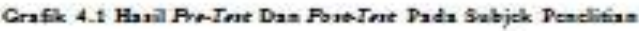

Berdasarkan grafik 4.I, hasil pre-test dan posttest subjek penelitian menunjukkan bahwa seluruh anggota kelompok yang terdiri dari 8 peserta didik yang teridentifikasi memiliki disiplin belajar yang cenderung sedang dan rendah berdasarkan hasil skala skor kedelapn subjek berada pada rentang 98 sampai dengan 150. Setelah diketahui skor kecenderungan disiplin peserta ddidik, kedelapan subjek penelitian mengikuti layanan bimbingan kelompok. Perlakuan berupa layanan bimbingan kelompok dilaksanakan sebanyak delapan pertemuan. Kondisi kedelapan subjek mengalami perubahan tingkat disiplin belajar yang dapat diketahui berdasrkan pengukuran menggunakan skala disiplin belajar (post-test) yang dilaksanakan setelah pemberian perlakuan berupa layanan bimbingan kelompok. Hasil post-test menunjukan bahwa kedelapan subjek mengalami peningkatan kecenderungan disiplin belajar, penurunan dapat dianalisis berdasarkan hasil skor skala disiplin belajar. Rentang skor yang diperoleh peserta didik yaitu 2I5 sampai dengan 25I. Kedelapan subjek mengalami peningkatan kecenderungan disiplin belajar juga dapat dilihat dari hasil rubrik observasi yang dilakukan oleh peneliti dan observer.

Penelitian penurunan perilaku disiplin belajar peserta didik dapat dilihat dari hasil pengujian hipotesis statistik Paired-Sample $T$ Test. Penghitungan menggunakan SPSS 20.00. hasil perhitungan dengan menggunakan aplikasi SPSS 20.00 disajikan dalam tabel sebagai berikut:

\begin{tabular}{|c|c|c|c|c|c|}
\hline \multicolumn{6}{|c|}{ Tabel 42 Paired Sampla Statitia } \\
\hline & & $\mathrm{Men}$ & $\mathrm{N}$ & Sts. Deriatien & Sed. Ener Men \\
\hline \multirow{2}{*}{$D=1$} & Detat & 130,13 & $\overline{8}$ & 10,839 & 7,014 \\
\hline & Derea & 234,13 & 3 & 12,643 & 4.470 \\
\hline
\end{tabular}

Tabel Paired Samples Statistics menunjukkan bahwa disiplin belajar mengalami peningkatan rata-rata. Berdasarkan hasil pre-test keseluruhan subjek penelitian memperoleh 
Jurnal Bimbingan dan Konseling

mean atau rata-rata 130,13. Setelah dilaksanakan layanan bimbingan kelompok, dilaksanakan post-test. Berdasarkan hasil pretest keseluruhan subjek penelitian memperoleh mean atau rata-rata 2034.I3. terjadi peningkatan rata-rata, sebesar 104. N adalah jumlah sabjek penelitian yang berjumlah 8 orang. Std. Deviation adalah nilai yang digunakan untuk menentukan bagaimana sebaran data dalam sampel, dan seberapa dekat titik data individu ke mean nilai sampel. Std. Deviation pada saat pre-test 19,838 dan pada saat post-test 12,643. Std. Error Mean adalah indeks yang menggambarkan sebaran mean sampel terhadap sebaran mean keseluruhan kemungkinan sampel. Std. Error Mean pada saat pre-test7,0I4, 7,014 pada saat post-test 4,4705.

\section{KESIMPULAN}

Berdasarkan hasil analisis dan pembahasan di atas, maka dapat disimpulkan bahwa Layanan Bimbingan Kelompok dapat Meningkatkan Disiplin Belajar Peserta Didik MTS Miftahul Jannah Palangka Raya Tahun Ajaran 2016/2017. Hal tersebut didasarkan pada hasil uji Paired-Sample T Test, menunjukkan bahwa belajar mengalami peningkatan rata-rata awal 130, I 3 menjadi 234,13. Artinya Hasil analisis menunjukan bahwa kedelapan peserta didik pada subjek penelitian mengalami peningkatan disiplin belajar sesudah dilakukan intervensi.

\section{DAFTAR PUSTAKA}

Arikunto, S. 2006. Prosedur Penelitian Suatu Pendekatan Praktek. Jakarta: Renika Cipta.

Kemendikbud, (20I4). Materi Pelatihan Implementasi Kurikulum 2013. Bimbingan dan Konseling SMP/MTs. Modul 4.

Kusumawati, D. A. 2012. Hubungan Antara Disiplin Belajar Siswa dengan Prestasi Balajar Pada Aspek Kognitif Pada Mata Pelajaran PKn Kelas VIII di SMP Negri I Ngadirejo Kecamatan Ngadirejo
Kabupaten Temanggung Semester II Tahun Ajara 201 I/20I2. Skripsi Jurusan Pkn Fakultas Ilmu Pendidikan Universitas Kristen Stya Wancana.

Nurihsan, Achmad Juntika. 2010. Bimbingan dan Konseling dalam Berbagai Latar Kehidupan. Bandung: Refika Aditama.

Prayitno \& Amti (2009). Dasar-Dasar Bimbingan dan Konseling. Jakarta: PT Rineka Cipta

Pujawati. 2016. Hubungan kontrol diri dan dukungan orang tua dan perilaku disiplin pada santri dipondok pesantren darussa'adah samarinda. Jurnal psikologi, 4 (2) 2016: 227-236. Fisipunmul. ISSN 2477-2674.

Roshita, I. 2014. Meningkatkan Kedisiplinan Siswa melalui layanan Bimbingan Kelompok Dengan Tehnik Modeling. Didaktikum: Jurnal Penelitian Tindakan Kelas Vol. 16, No. 2, Oktober 2014 ISSN 2087-3557

Romlah, T. 200I. Teknik-Teknik Bimbingan dan Konseling Kelompok. Malang: Universitas Negeri Malang.

Sukardi. K. Dewa (2008). Pengantar Pelaksanaan Program BBimbingan dan Konseling di Sekolah. (Edisi Revisi). Jakarta: PT.Rineka Cipta

Slameto. 2010. Belajar dan Faktor-Faktor Yang Mempengaruhinya. Jakarta: Rineka Cipta

Sukardi. K. Dewa. (20I0). Bimbingan dan Penyuluhan di Sekolah. Usaha Nasional Surabaya-Indonesia

Sobri, M. \& Moerdiyanto. 20I4. Pengaruh Kedisiplinan Dan Kemandirian Belajar Terhadap Hasil Belajar Ekonomi Madrasah Aliyah Di Kecamatan Praya. Jurnal Harmoni Sosial, Volume I Nomor I.

Sari, W. A. 2009. Upaya Meningkatkan Perilaku Disiplin Siswa Melalui Layanan Bimbingan Kelompok (Penelitian Pada Siswa Kelas 8 Di SMP N II Semarang Tahun Ajaran 2008/ 2009). Skripsi Jurusan Bimbingan Dan Konseling Fakultas IImu Pendidikan Universitas Negeri Semarang.

Tu'u. T. (2009). Peran Disiplin pada Perilaku dan Prestasi Siswa. Jakarta : PT Gramedia Widia Sarana Indo 


\section{Jurnal Bimbingan dan Konseling}

Wibowo, M E. 2005. Konseling Kelompok Perkembangan. UPT UNNES Press.

Yusuf, S.(20I2). Psikologi Perkembangan Anak dan Remaja.Bandung: PT Remaja Rosdakarya. 